\title{
Resistance to Ara-C Up-Regulates the Activation of NF- $K B$, Telomerase Activity and Fas Expression in NALM-6 Cells
}

\author{
Syu-ichi Kanno, ${ }^{*}$ Takako Hiura, Ai Shousi, Yuu Osanai, Mayuko Usibe, and Masaaki Ishikawa \\ Department of Clinical Pharmacotherapeutics, Tohoku Pharmaceutical University; 4-4-1 Komatsushima, Aoba-ku, \\ Sendai 981-8558, Japan. Received May 30, 2007; accepted August 13, 2007; published online August 20, 2007
}

\begin{abstract}
Cytosine arabinoside (1- $\beta$-D-arabinofuranosylcytosine; Ara-C) is the most important antimetabolite used to induce remission in acute leukemia, but cellular resistance to Ara-C reflects a poor prognosis in cancer chemotherapy. To further investigate the mechanisms of resistance to Ara-C, we have established Ara-C-resistant NALM-6 cells. The activation of nuclear factor $\kappa B(N F-\kappa B)$ was accompanied by the acquisition of Ara-C resistance. Telomerase activity has also increased with the acquisition of Ara-C resistance. The expression of Bid, Bax, or p53 proteins have been shown to increase correlated with the acquisition of Ara-C resistance. In contrast to the increase in these proteins, Bcl-2, Bcl-x, and Bag-1 proteins remained unchanged with the acquisition of Ara$\mathrm{C}$ resistance. Fas expression increased with the acquisition of $\mathrm{Ara}-\mathrm{C}$ resistance in the late stage. The induction of apoptosis and reduction of cell viability by cytotoxic anti-Fas antibody was more susceptible in resistant cells than parental cells. In conclusion, this report has shown that resistance to Ara-C up-regulates the activation of $\mathrm{NF}-\kappa \mathrm{B}$, telomerase activity and Fas expression.
\end{abstract}

Key words $\quad 1-\beta$-D-arabinofuranosylcytosine; resistance; nuclear factor $\kappa \mathrm{B}$; telomerase; Fas; p53

Leukemia is one of the most effectively treated cancers by chemotherapy; however, resistance to chemotherapeutics agents is a major obstacle for the successful treatment of leukemia, the mechanisms for which are determined by multiple factors. Cytosine arabinoside (1- $\beta$-D-arabinofuranosylcytosine; Ara-C) is the most important antimetabolite used to induce remission in children and adults with acute leukemia. ${ }^{1)}$ The clinical importance of Ara-C has stimulated extensive laboratory investigations aimed at understanding the biochemical correlations of drug action and mechanisms of drug resistance to provide ideas for better therapeutic strategies.

Nuclear factor $\kappa \mathrm{B}(\mathrm{NF}-\kappa \mathrm{B})$, a nuclear transcription factor, was first identified by Sen and Baltimore to regulate the expression of various gene products or molecules. ${ }^{2)}$ A growing of evidence suggests that activation of NF- $\kappa \mathrm{B}$ negatively regulates apoptotic event in cancer cells, although classical pro-apoptotic role is still suggested. ${ }^{3)}$ Ara-C and several chemotherapeutic agents such as doxorubicin and daunorubicin, taxol, vinblastine and vincristine, have been reported to activate NF- $\kappa \mathrm{B} .{ }^{4-7)}$ Romano et al. indicated that NF- $\kappa \mathrm{B}$ activity influenced response to Ara-C in human primary myeloblastic cells. ${ }^{8)} \mathrm{NF}-\kappa \mathrm{B}$ activation induces resistance to chemotherapeutic agents. ${ }^{9-11)}$ Recently, translocation into the nucleus of NF- $\kappa \mathrm{B}$ has been shown to contribute to the activation of telomerase. ${ }^{12,13)}$ Telomerase is a cellular reverse transcriptase that catalyzes the synthesis and extension of telomeric DNA. ${ }^{14,15)}$ High levels of telomerase activation are associated with treatment failure ascribable to chemo-resistant of leukemia. ${ }^{16)}$

The cellular response to cytotoxic drugs including chemotherapeutic agents may be modulated by oncogenes such as p53 or pro-apoptotic and anti-apoptotic proteins of the Bcl-2 family, both of which have been correlated clinically with a poor response to treatment. ${ }^{17)}$ These apoptosisrelated proteins including p53 and the Bcl-2 family, and other many factors, are also known to regulate Fas expression. ${ }^{18)}$ A direct role for Fas-induced apoptosis in the response to chemotherapy is supported by the clinical finding that increased expression of Fas on tumor cells is associated with a better initial response to treatment. ${ }^{19)}$ We have addressed the possibility that Ara-C resistance may confer Fas expression.

Previously, we have shown that NALM-6, a B-cell line of acute lymphoblastic leukemia, was most susceptible to AraC-induced cytotoxicity among a number of typical human leukemia cell lines, and the induction of cytotoxicity and apoptosis by Ara-C were dependent on $\mathrm{p} 53$ accumulation involving an increase in the production of reactive oxygen species in leukemia cell lines. ${ }^{20)}$ Cellular resistance to Ara-C reflects a poor prognosis in cancer chemotherapy, and a need to change to other anticancer drugs. Many reports have examined resistance to Ara-C, but few have studied the acquisition stage of resistance. To further investigate the mechanisms of resistance to Ara-C, we have established Ara-C-resistant NALM-6 cells, and showed that a decrease in uptake was causatively responsible for the acquisition of Ara-C resistance and alternations in an activation or an inactivation enzyme contributed to the higher concentration range. ${ }^{21)}$ In this study, we have attended to other factors and examined whether Ara-C resistance related to the activation of NF- $\kappa \mathrm{B}$, telomerase activity and Fas expression.

\section{MATERIALS AND METHODS}

Cell Culture Reagents NALM-6 cells were supplied by the Cell Resource Center for Biomedical Research, Tohoku University (Sendai, Japan). Cells were routinely kept in RPMI 1640 medium supplemented with $10 \%$ fetal bovine serum and penicillin $\mathrm{G}(100 \mathrm{U} / \mathrm{ml}) /$ streptomycin $(100 \mu \mathrm{g} / \mathrm{ml})$ at $37^{\circ} \mathrm{C}$ in a humidified $5 \% \mathrm{CO}_{2}-95 \%$ air incubator under standard conditions. ${ }^{22)}$ Cell viability was measured by counting the cells, excluding those stained with $0.2 \%$ trypan blue. Ara-C-resistant NALM-6 cells were isolated from parental NALM-6 cells by a series of stepwise selections with Ara-C treatment, as previously described. ${ }^{21)}$ Briefly, resistance to Ara-C was acquired by making stepwise increases in the drug concentration from $0.5 \mathrm{~nm}$ (usually at intervals of 8 pas- 
sages). Two separate flasks were incubated in parallel and the concentration of the drug was increased 1.2- to 2.0-fold. Finally, a concentration of $1 \mu \mathrm{M}(=1000 \mathrm{nM})$ is clinically achievable in situations where a standard dose of Ara-C is administered $^{23)}$; therefore, we have established NALM-6 cell lines resistant to Ara-C concentrations of up to $1 \mu \mathrm{M}$ (NALM-6/Ara-C). To examine the stage of resistant to Ara$\mathrm{C}$, we have subcultured at 3,10, 30, 100, 300 and $1000 \mathrm{~nm}$ of Ara-C during increasing concentration of the drug. To maintain exponential growth, cells were seeded at $1 \times 10^{5}$ cells $/ \mathrm{ml}$ and passaged every 4 to $5 \mathrm{~d}$. The cells were cultured at $4 \times 10^{5}$ cells $/ \mathrm{ml}$ in $100 \mu \mathrm{l}$ in separate wells of 96 -well plates for the cytotoxicity assay or in 2-ml amounts in 35-mm dishes for other assays. The drugs used in these experiments, Ara-C and all reagents, were of the highest grade available and were supplied by either Sigma (St. Louis, MO, U.S.A.) or Wako Pure Chemical Industries, Ltd. (Osaka, Japan). All cell culture reagents were obtained from Invitrogen Corp. (Carlsbad, CA, U.S.A.). Ara-C was dissolved in phosphatebuffered saline (PBS) and stored as a $10 \mathrm{~mm}$ stock solution. Light exposure was kept to a minimum for all drugs used. Anti-Bcl-2 family or Sp1 antibodies were purchased from BD Biosciences Pharmingen (San Diego, CA, U.S.A.), anti$\beta$-actin, NF- $\kappa \mathrm{B}$ p $65, \mathrm{NF}-\kappa \mathrm{B}$ p50 and 553 antibodies were from Cell Signaling Technology (Danvers, MA, U.S.A.), anti-Fas antibody (CH-11) was from MBL (Nagoya, Japan), and anti-Fas antibody conjugated R-Phycoerythrin (R-PE) was from Ancell (Bayport, MN, U.S.A.).

Electrophoretic Mobility Shift Assay (EMSA) Nuclear extracts $\left(4 \times 10^{6}\right.$ cells $)$ were prepared using NE-PER Nuclear and Cytoplasmic Extraction Reagents (Pierce Chemical Co., Rockford, IL, U.S.A.), according to the manufacturer's instructions. The activation of NF- $\kappa \mathrm{B}$ was assayed by EMSA using nuclear extracts from control and treated cells. For EMSA, the NF- $\kappa$ B-specific oligonucleotide was end-labeled with $\left[\gamma-{ }^{32} \mathrm{P}\right]$-ATP using $\mathrm{T}_{4}$ polynucleotide kinase (Promega, Madison, WI, U.S.A.) and purified using a microspin G-25 column (Amersham Inc., Piscataway, NJ, U.S.A.). EMSA was performed according to the instruction manual of Promega. Nuclear protein $3 \mu \mathrm{g}$, binding buffer, ${ }^{32} \mathrm{P}$-labeled $\mathrm{NF}-\kappa \mathrm{B}$, and loading buffer were incubated for $30 \mathrm{~min}$ at room temperature. In competition assays, a 100-fold excess of unlabeled NF- $\kappa$ B was added $10 \mathrm{~min}$ before addition of the radiolabeled probe. DNA-protein complexes were separated from an unbound DNA probe by electrophoresis through $6 \%$ polyacrylamide gel using $0.5 \times \mathrm{TBE}$ as the running buffer. The gels were visualized and the bands measured using an image analyzer BAS-5000 (Fujifilm, Tokyo, Japan).

Telomerase Activity Assay Telomerase activity was measured using a PCR-based telomeric repeat amplification protocol (TRAP) enzyme-linked immunosorbent assay (ELISA) kit (Roche, Basel, Switzerland) according to the manufacturer's description. In brief, $2 \times 10^{5}$ cells were lysed in $200 \mu \mathrm{l}$ lysis reagent and incubated on ice for $30 \mathrm{~min}$. For TRAP reaction, $2 \mu \mathrm{l}$ of cell extract (containing $2 \mu \mathrm{g}$ protein) was added to $25 \mu \mathrm{l}$ reaction mixture with the appropriate amount of sterile water to make a final volume of $50 \mu \mathrm{l}$. PCR was performed in a thermal cycler as follows: primer elongation $\left(30 \mathrm{~min} ; 25^{\circ} \mathrm{C}\right)$, telomerase inactivation $\left(5 \mathrm{~min} ; 94^{\circ} \mathrm{C}\right)$, product amplification by repeat of 20 cycles $\left(94^{\circ} \mathrm{C}\right.$ for $30 \mathrm{~s}$, $50{ }^{\circ} \mathrm{C}$ for $30 \mathrm{~s}$, and $72^{\circ} \mathrm{C}$ for $90 \mathrm{~s}$ ). Hybridization and ELISA reaction were carried out following the manufacturer's instructions.

Western Blotting The cells were washed with PBS and lysed in CelLytic M (Sigma, St. Louis, MO, U.S.A.) to detection for Bcl-2 family and p53. Nuclear extracts (for Sp1, NF$\kappa \mathrm{B}$ p65 and NF- $\kappa \mathrm{B}$ p50) were prepared by NE-PER Nuclear and Cytoplasmic Extraction Reagents, according to the manufacturer's instructions. Samples of $30 \mu \mathrm{g}$ of each protein were loaded onto a 10\% SDS-polyacrylamide gel. After electrophoresis, the protein was transferred to a PVDF membrane. PVDF was blocked with blocking solution $(25 \mathrm{~mm}$ Tris- $\mathrm{HCl} \mathrm{pH} \mathrm{7.4,} 137 \mathrm{~mm} \mathrm{NaCl}, 2.68 \mathrm{~mm} \mathrm{KCl}$ and 10\% skim milk) for $4 \mathrm{~h}$ and reacted with antibody overnight at $4{ }^{\circ} \mathrm{C}$. The membrane was then washed with blocking solution without skim milk, and incubated with horseradish peroxidaselinked secondary antibody for $1 \mathrm{~h}$. After washing again, the levels of protein were analyzed by enhanced chemiluminescence with an ECL plus Western blotting detection system (Amersham, Arlington Heights, IL, U.S.A.). The each protein has confirmed the detection with control $\operatorname{IgG}$ to ensure the accuracy of Western blot analysis as control experiment.

Flow Cytometry The expression of Fas on parental NALM-6 cells and resistance to NALM-6/Ara-C cells was determined by flow cytometry in non-permeabilized cells. Briefly, $2 \times 10^{5}$ cells were washed with PBS and incubated for $45 \mathrm{~min}$ on ice with $80 \mu \mathrm{l}$ of R-PE labeled anti-Fas antibody. After washing in PBS once more, the cells were immediately analyzed using a FACScan flow cytometer (Becton Dickinson, San Diego, CA, U.S.A.). A minimum of 10000 events was acquired for each sample. The fluorescence profile was determined and the mean fluorescence index calculated using CellQuest software (Becton Dickinson, San Diego, CA, U.S.A.).

Cytotoxicity and Apoptosis Cytotoxicity was assessed by the MTT [3-(4,5-dimethylthiazol-2-yl)-2,5-diphenyl tetrazolium bromide] assay, a modification of our previously described method. ${ }^{21,22)}$ Following the treatment of cells with Ara-C or anti-Fas antibody (CH-11), $10 \mu \mathrm{l}$ of MTT $(5 \mathrm{mg} / \mathrm{ml}$ saline) was added to each well, the samples incubated for $90 \mathrm{~min}$ at $37^{\circ} \mathrm{C}$ and then centrifuged $(300 \times \boldsymbol{g}$ for $5 \mathrm{~min})$, and the supernatant aspirated. The cells were lysed and solubilized by the addition of $100 \mu \mathrm{l}$ of $0.04 \mathrm{~N} \mathrm{HCl}$ in isopropanol. The absorbance of each well was determined at $590 \mathrm{~nm}$ using an Inter-med model NJ-2300 Microplate Reader. Survival (\%) was calculated relative to the control. Apoptosis was estimated by the change of nuclear morphology. Cells were collected by centrifugation and washed with PBS. Cells were stained for $10 \mathrm{~min}$ at room temperature in PBS containing $5 \mu \mathrm{M}$ bisbenzimide $\mathrm{H} 33342$ fluorochrome trihydrochloride (H 33342) and observed under a fluorescence microscope, TE 300 (Nikon, Tokyo, Japan) through excitation and emission filters of 360 and $420 \mathrm{~nm}$, respectively. Apoptosis was characterized by chromatin condensation followed by partition into multiple bodies. At least 300 cells were counted in each experiment, and the percentage of apoptotic cells was calculated.

Statistical Analysis Statistical analysis of the results was performed by one-way analysis of variance (ANOVA) followed by Scheffe's $F$ test. A $p$-value of less than 0.05 was considered significant. 


\section{RESULTS}

Effects of NF- $\boldsymbol{K B}$ Activation First, we examined the basal activation of NF- $\kappa \mathrm{B}$ in the acquisition stage of resistance to Ara-C from 3 to $1000 \mathrm{~nm}$ using by EMSA. As shown in Fig. 1A, the basal activation of NF- $\kappa \mathrm{B}$ extremely increased until the resistant concentration of Ara-C at $10 \mathrm{~nm}$ and then continually increased. The addition of excess unlabelled consensus oligonucleotide completely prevented the band shifts, demonstrating the specificity of protein/DNA interaction. We tested if resistant to Ara-C perturbed the distribution of NF- $\kappa$ B subunits (p65, p50) as assessed by nuclear accumulation (Fig. 1B). Sp1, a nuclear protein was used as loading control for Western blotting. The amounts of each $\mathrm{NF}-\kappa \mathrm{B}$ subunit were increased following up to Ara-C resistant.

Effects of Telomerase Activity Next, we examined telomerase activity, using by TRAP ELISA kit. The basal telomerase activity of each Ara-C-resistant stage of NALM-6 cells at $3,10,30,100,300$, or $1000 \mathrm{~nm}$ was concentrationdependently increased in $131.2 \%, 149.6 \%, 157.3 \%, 181.4 \%$, $223.4 \%$ or $256.6 \%$ compared with parental NALM-6 cells $(100 \%)$, respectively (Fig. 2). This result suggests that basal telomerase activity increased with the acquisition of Ara-C

A

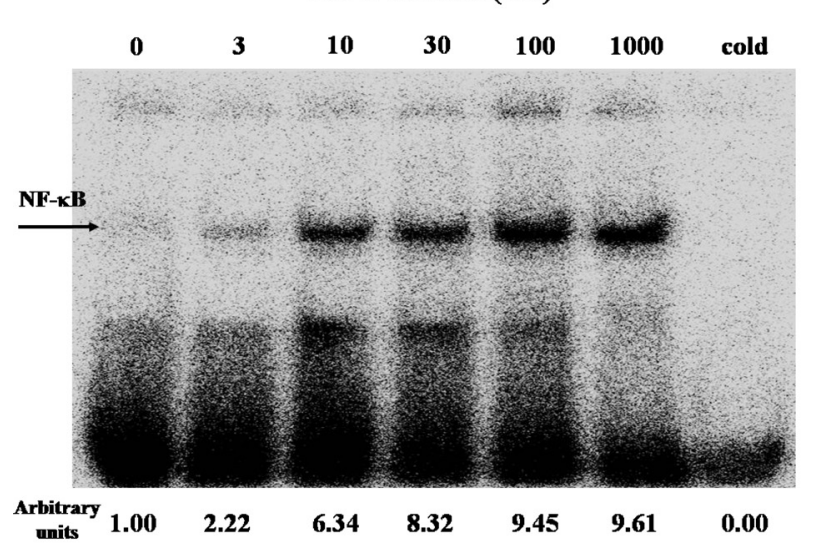

B

Ara-C resistant (nM)
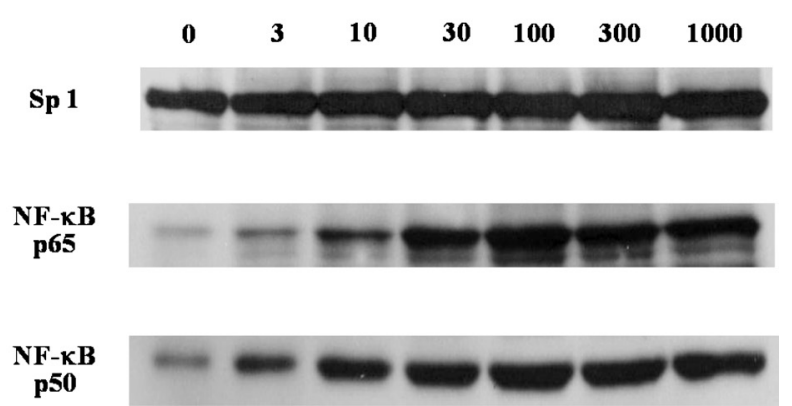

Fig. 1. Effects of NF- $\kappa$ B Activation on Resistance to Ara-C NALM-6 Cells

(A) Effects of NF- $\kappa$ B activation were assayed by electrophoretic mobility shift assay (EMSA), as described under Materials and Methods. The bands of NF- $\kappa$ B activation were measured with an image analyzer, expressed as arbitrary units. (B) Detection of $\mathrm{NF}-\kappa \mathrm{B}$ subunits $(\mathrm{p} 65, \mathrm{p} 50)$ by Western blotting. Basal level of NF- $\kappa \mathrm{B}$ in resistance to Ara-C at 0 (parental cells), 3, 10, 30,100, or 1000 nm NALM-6 cells. Similar results were obtained in three separate sets of experiments. resistance.

Effects of Expression of Bcl-2 Family Proteins or p53 Protein The cytotoxic mechanism of Ara-C is involved in apoptosis. Several previous studies show the alternative expression of Bcl-2 family proteins and p53 protein were revealed in the apoptotic mechanism by Ara-C. We examined the effects of the expression of Bcl-2 family proteins or $\mathrm{p} 53$ protein on the acquisition of Ara-C resistance by Western blotting (Fig. 3). $\beta$-Actin as a positive control has shown to have an invariable expression in each sample. The expression of $\mathrm{Bid}, \mathrm{Bax}$, or $\mathrm{p} 53$ proteins have been shown to increase associated with the acquisition of Ara-C resistance. In contrast to the increase in Bid or Bax proteins, Bcl-2, Bcl-x, and Bag1 proteins remained unchanged with the acquisition of Ara-C resistance.

Effects of Fas Expression To determine whether acquisition of resistant to Ara-C involves Fas expression, the surface expression of Fas antigen was determined by flow cy-

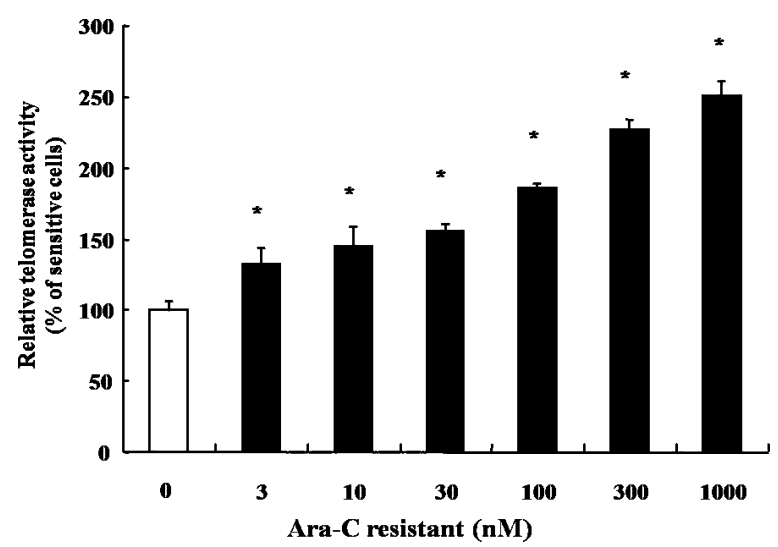

Fig. 2. Effects of Telomerase Activity on Resistance to Ara-C NALM-6 Cells

Effects of telomerase activity were measured using a PCR-based telomeric repeat amplification protocol (TRAP) enzyme-linked immunosorbent assay (ELISA) kit, as described under Materials and Methods. Basal levels of telomerase activity in resistance to Ara-C at 0 (parental cells), 3, 10,30,100, 300 or $1000 \mathrm{~nm}$ NALM-6 cells. $* p<0.05 v s$. parental NALM-6 cells. Each value represents the mean \pm S.E. for three different experiments performed in triplicate.

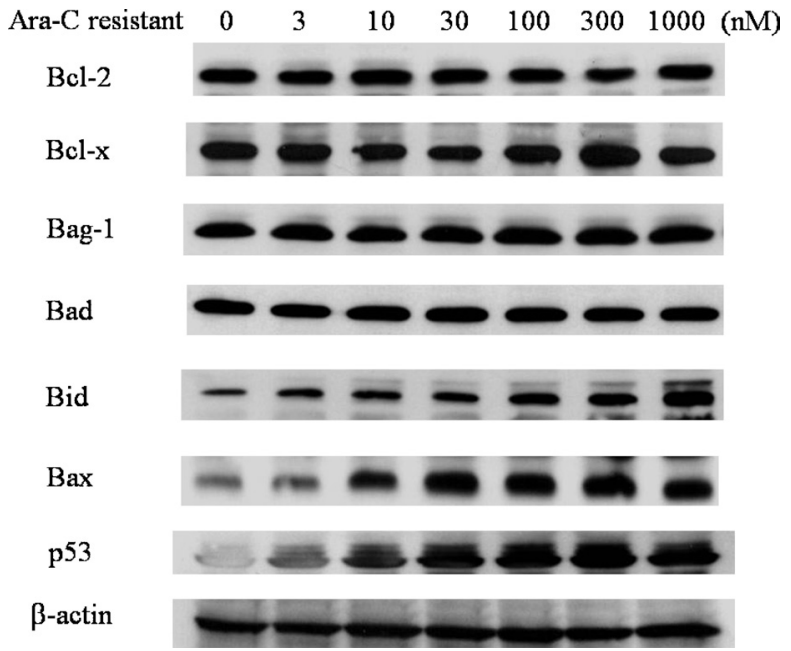

Fig. 3. Effects of p53 and Bcl-2 Family Proteins on Resistance to Ara-C NALM-6 Cells

Expressions of these proteins were detected by Western blotting, as described in Materials and Methods. Similar results were obtained in three separate sets of experiments. 
$\mathbf{A}$

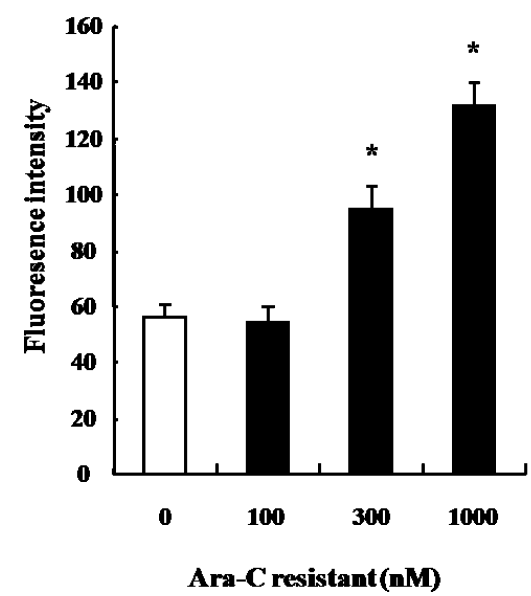

B

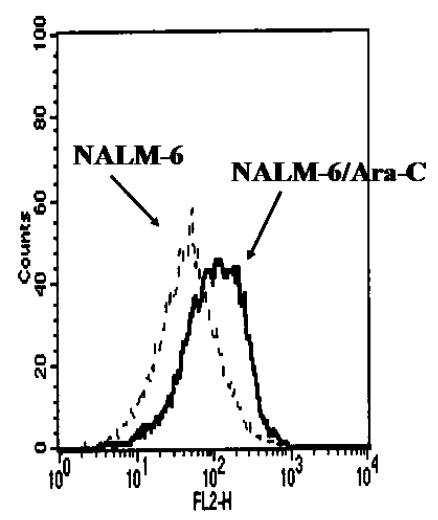

Fig. 4. Effects of Fas Expression on Resistance to Ara-C NALM-6 Cells

Effects of Fas expression detected using flow cytometric analysis, as described in Materials and Methods. Anti-Fas antibody-conjugated R-Phycoerythrin (R-PE) was used to probe the expression of Fas. Fas expression was shown as the intensity of fluorescence of R-PE-labeled anti-Fas antibody incorporated into cells that comprised the largest population in each sample. (A) Basal level expression of Fas in resistance to Ara-C in 0 (parental cells), 100, 300, or 1000 nM NALM-6 cells. * $p<0.05 v s$. parental NALM-6 cells. Each value represents the mean \pm S.E. for three different experiments performed in triplicate. (B) Typical histogram profile of Fas expression by flow cytometry in NALM-6 (parental) cells or NALM-6/Ara-C (Ara-C $1 \mu \mathrm{m}$ resistant) cells.

tometry using R-PE labeled anti-Fas antibody (5E2). As shown in Fig. 4, at the basal line in resistant cells, there was no change until $100 \mathrm{~nm}$, but a significant increase at $300 \mathrm{~nm}$ $(163.7 \%)$ and $1000 \mathrm{~nm}(218.6 \%)$. Fas expression was increased in the acquisition of Ara-C resistance in the late stage. We wondered whether cytotoxic anti-Fas antibody would be susceptible to Ara-C resistant cells compared to parental cells. The induction of apoptosis or reduction of cell viability by anti-Fas antibody was determined by incubation with anti-Fas antibody $(\mathrm{CH}-11 ; 100 \mathrm{ng} / \mathrm{ml})$ for 12,24 , or $48 \mathrm{~h}$ (Fig. 5). Apoptosis was confirmed by nuclear morphological observation and cytotoxicity was estimated by MTT assay. The induction of apoptotic cells with anti-Fas antibody incubation for 12,24 , or $24 \mathrm{~h}$ in NALM-6 cells was $12.5 \%$, $34.4 \%$, or $56.7 \%$, in NALM-6/Ara-C (Ara-C $1 \mu \mathrm{M}-$ resistant NALM-6) cells was $40.2 \%, 62.4 \%$, or $79.8 \%$, respectively (Fig. 5A). Similarly, the reduction of cell viability by anti-Fas antibody for 12,24 , or $48 \mathrm{~h}$ was greater in NALM-6/Ara-C cells, $61.4 \%, 36.4 \%$, or $20.5 \%$ than in NALM- 6 cells, $92.5 \%$, $66.2 \%$, or $39.8 \%$, respectively (Fig. $5 \mathrm{~B}$ ).

\section{DISCUSSION}

As chemotherapeutic agent-induced resistance is a major problem in cancer, understanding the basic mechanism will be helpful in addressing this problem. Ara-C-induced cytotoxicity has been indicated in several cellular signal transduction mechanisms or apoptosis-related proteins. For some of these agents, we focused on the effects of NF- $\kappa \mathrm{B}$, telomerase activity and Fas expression on the acquisition of Ara-C resistance in NALM-6 cells in this report.

It has been found that most chemotherapeutic agents activate NF- $\kappa$ B. The activation of NF- $\kappa$ B by Ara-C is reportedly mediated by a protein kinase $\mathrm{C}$-dependent mechanism. ${ }^{4}$ The activation of NF- $\kappa \mathrm{B}$ is required for apoptosis, as has also been shown for oxidative stress inducers such as $\mathrm{H}_{2} \mathrm{O}_{2}{ }^{24)} \mathrm{Ox}$ idative stress may play an important role in apoptosis medi-
$\mathbf{A}$

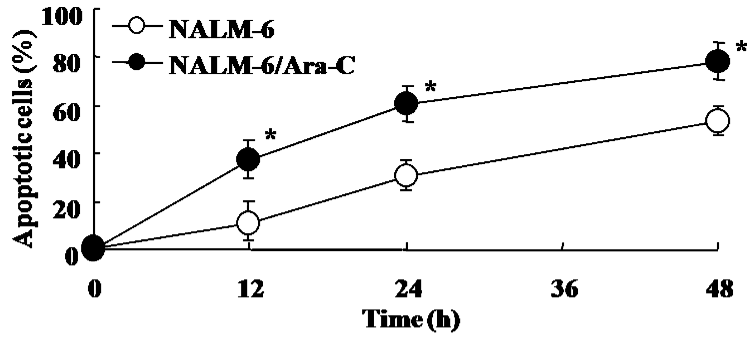

B

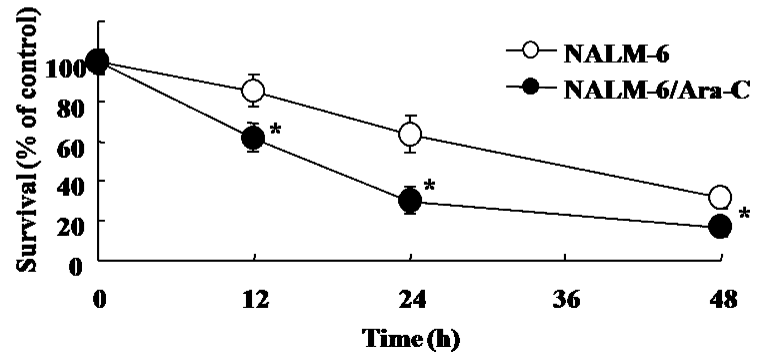

Fig. 5. Effects of Cytotoxic Anti-Fas (CH-11) Antibody-Induced Cytotoxicity and Apoptosis on Parental Cells and Ara-C-Resistant Cells

Following exposure to anti-Fas antibody (CH-11) at $100 \mathrm{ng} / \mathrm{ml}$ in NALM-6 (parental) cells or NALM-6/Ara-C (Ara-C $1 \mu \mathrm{M}$ resistant) cells for indicated time, (A) apoptotic cells were estimated based on changes in nuclear morphology, (B) cytotoxicity was evaluated using the MTT assay, as described in Materials and Methods. $* p<0.05 v s$. parental NALM- 6 cells. Each value represents the mean \pm S.E. for three different experiments performed in triplicate.

ated by the activation of NF- $\kappa \mathrm{B} .{ }^{3)}$ The apoptotic mechanism induced by Ara-C involvement of oxidative stress has previously been shown in human leukemia cell lines. ${ }^{20,25)}$ We suppose that one of the activation mechanisms of NF- $\kappa \mathrm{B}$ also depends on oxidative stress by Ara-C. The activation of NF$\kappa \mathrm{B}$ can lead to resistance to apoptosis and cytotoxicity induced by chemotherapy. The involvement of an increase in the activation of NF- $\kappa \mathrm{B}$ in resistance to doxorubicin has been reported. ${ }^{9)}$ The activation of NF- $\kappa \mathrm{B}$ was also involved in the increase in the early acquisition of Ara-C resistance (Fig. 1). One of the proteasome inhibitor, $N$-acetyl-L- 
leucinyl-L-leucinyl-L-norleucinal ( $\mathrm{LLnL})$, which is known to inhibit activation of $\mathrm{NF}-\kappa \mathrm{B} .{ }^{9)}$ It has shown that it could be reversed the resistance to tumor necrosis factor-related apoptosis-inducing ligand (TRAIL) in melanoma cells. ${ }^{26)}$ We have examined the reversal effect of LLnL on resistance to Ara-C in NALM-6 cells, but there was no significant effect (data not shown). There are several hundred different types of NF$\kappa \mathrm{B}$ inhibitors, each aiming at reducing the activation of NF$\kappa \mathrm{B}^{27)}$ We are currently examining whether to reverse the Ara-C resistant by other types of NF- $\kappa \mathrm{B}$ inhibitors.

Telomeres are essential units that stabilize the ends of eukaryotic chromosomes and prevent the loss of genetic information. Most tumor cells have mechanisms that compensate for telomere shortening, most commonly through the activation of telomerase, allowing them to stably maintain their telomeres and grow indefinitely. It has been suggested that telomerase might be an important factor in suppressing apoptosis signaling cascades. ${ }^{28,29)}$ As indicated in Fig. 2, basal activity increased with the acquisition of Ara-C resistance. The results suggest that the increase of telomerase activity by Ara-C is associated with up-regulation by long-term stimulation. Other studies observed different basal telomerase activity in drug-resistant cells compared with drug-sensitive controls. ${ }^{30-32)}$ Another study reported that telomerase activity increased upon long-term treatment of human colorectal carcinoma cells with cisplatin and 5-fluorouracil. ${ }^{33)}$ These observations support our results (Fig. 2). It is tempting to speculate that changes in basal telomerase activity, in general, may contribute to the development or maintenance of chemotherapeutic resistance.

Cell proliferation and survival are largely due to the activation of tumor suppressor p53, which plays a key role in eliminating cells with DNA damage, namely p53 is crucial for preventing cancer. ${ }^{34)}$ Our previous report has shown that NALM-6 was most susceptible to Ara-C in among leukemia cell lines, because it has higher p53 accumulation than other cells ${ }^{20)}$ and decreased uptake was causatively responsible for the acquisition of Ara-C resistant in NALM- 6 cells. ${ }^{21)}$ In the present study, the resistant cells over expressed p53 (Fig. 3). These results suggest that there are different factors between susceptible to Ara-C by a single incubation in each leukemia cell lines and resistant to Ara-C by long-term incubation in the same cells. The p53 has been shown to regulate apoptosis-related signal transduction in numerous studies. Our lab, and others have reported that Ara-C involved p53 accumulation in the induction of apoptosis, ${ }^{1,20,25)}$ so it may change several chemoresistant factors. Bcl-2 family protein has indicated changes in the expression of several different types of chemotherapeutic-resistant cell lines. ${ }^{35)}$ As shown in Fig. 3, the expression of Bid and Bax proteins has been shown to increase with the acquisition of Ara-C resistance. Bid has not been indicated to play an essential role in Ara-C-induced neuronal cell death in other reports ${ }^{36,37)}$; nevertheless, Bid has shown to increase the acquisition of resistance to Ara-C in our results (Fig. 3). How is the mechanism up-regulation in resistant cells? This phenomenon has not yet been elucidated. We speculate that a number of factors are implicated in the acquisition of chemoresistance, so the expression of Bid will change in this study. The pro-apoptotic Bcl-2 family, Bax has an important function in Ara-C-induced cell death. ${ }^{37)}$ This report supports that our data correspond to the increase in expression of Bax that depends on long-term incubation with Ara-C and the acquisition of resistance. In contrast to the pro-apoptotic Bcl-2 family, anti-apoptotic Bcl2, Bcl-x, and Bag-1 proteins remained unchanged between parental and resistant cells. The expression of $\mathrm{Bcl}-2$ protein has indicated the difference in individual Ara-C-resistant cells, and it has shown that Ara-C resistant cells confer crossresistance to many other classes of drugs and gamma radiation, due to $\mathrm{Bcl}-2$ protein. ${ }^{38)}$ Our previous report has shown to Ara-C-resistant NALM-6 cells were not cross-resistant with other types of chemotherapy agents, except similar nucleoside analogues, such as cladribine, fludarabine, and gemcitabine. $^{21)} \mathrm{Bcl}-2$ protein and other anti-apoptotic Bcl-2 family overexpression may lead to resistance to many other classes of drugs.

Apoptosis-related proteins including p53 and the Bcl-2 family, or other many factors have been known to regulate Fas expression. ${ }^{18)}$ A transcriptional factor, p53, is known to play a central role as a mediator of Fas expression in apoptosis induction by anticancer drugs, and it has also been shown that the expression of Fas was only regulated by wild-type (wt) p53 in cells, but a mutant or without any p53 in cells was not implicated. ${ }^{39)}$ NALM-6 cells expressed only the amount of wt p53, ${ }^{20)}$ so we speculate that wt p53 was accumulated by resistant to Ara-C (Fig. 3), and basal Fas expression increased with the acquisition of Ara-C resistance in the late stage (Fig. 4). Several chemotherapeutic drug-resistant cell lines were resistant to Fas-mediated apoptosis, except Ara-C, and there were different induction mechanisms of apoptosis between Fas and Ara-C. ${ }^{40}$ Finally, we examined the effect of cytotoxicity and the induction of apoptosis by cytotoxic anti-Fas antibody in both parental and resistant cells (Fig. 5). Cytotoxic anti-Fas showed more susceptible in resistant cells than parental cells. Induction of Fas-mediated apoptosis is regulated by p53 and other apoptotic signal transducers. ${ }^{41)}$ In the Ara-C resistant NALM-6 cells, it has over expressing p53 as well as other pro-apoptotic proteins (Fig. 3). These increases in pro-apoptotic proteins may contribute to susceptible on induction of apoptosis by cytotoxic anti-Fas antibody in resistant cells. The expression of Fas is indicated to be regulated by not only p53 activation or NF$\kappa \mathrm{B}^{42)}$ It has been reported that NF- $\kappa \mathrm{B}$ could induce expression of Fas through the direct binding to the promoter sequence. ${ }^{43)}$ Interestingly, these transcriptional factors have shown to earlier increase than expression of Fas in acquisition of Ara-C resistant (Figs. 1, 3). Our results indicate that the acquisition of Ara-C resistance by long-term incubation and stimulation by several apoptosis relating transcriptional pathways resulted in an increase in the expression of Fas. Thus, cytotoxic anti-Fas antibody overcame Ara-C-resistant NALM-6 cells.

In conclusion, this report has shown that the resistance of Ara- $\mathrm{C}$ relates to the activation of $\mathrm{NF}-\kappa \mathrm{B}$, telomerase activity and Fas expression. The activation of NF- $\kappa \mathrm{B}$ is assumed to induce transcription genes that encode gene products that function in feedback and block apoptosis. Telomerase activity and Fas expression are implicated in the transcription of $\mathrm{NF}-\kappa \mathrm{B}$. These alterations are also transregulated by each other or apoptosis-related proteins, such as p53, or the Bcl-2 family; therefore, acquisition of Ara-C resistance will likely be affected by alterations of any these components. 
Acknowledgments This work was supported by a Grantin-Aid for the High Technology Research Program from the Ministry of Education, Culture, Sports, Science and Technology of Japan.

\section{REFERENCES}

1) Grant S., Adv. Cancer Res., 72, 197-233 (1998).

2) Sen R., Baltimore D., Cell, 47, 921 -928 (1986).

3) Shishodia S., Aggarwal B. B., Biochem. Pharmacol., 68, 1071-1080 (2004).

4) Brach M. A., Kharbanda S. M., Herrmann F., Kufe D. W., Mol. Pharmacol., 41, 60-63 (1992).

5) Sreenivasan Y., Sarkar A., Manna S. K., Oncogene, 22, 4356-4369 (2003).

6) Boland M. P., Foster S. J., O’Neill L. A., J. Biol. Chem., 272, 12952 12960 (1997).

7) Das K. C., White C. W., J. Biol. Chem., 272, 14914-14920 (1997).

8) Romano M. F., Lamberti A., Bisogni R., Tassone P., Pagnini D., Storti G., Del Vecchio L., Turco M. C., Venuta S., Gene Ther., 7, 1234 1237 (2000).

9) Jeremias I., Kupatt C., Baumann B., Herr I., Wirth T., Debatin K. M., Blood, 91, 4624-4631 (1998).

10) Wang C. Y., Cusack J. C., Jr., Liu R., Baldwin A. S., Jr., Nat. Med., 5, 412-417 (1999).

11) Berenson J. R., Ma H. M., Vescio R., Semin. Oncol., 28, 626-633 (2001).

12) Akiyama M., Hideshima T., Hayashi T., Tai Y. T., Mitsiades C. S., Mitsiades N., Chauhan D., Richardson P., Munshi N. C., Anderson K. C., Cancer Res., 63, 18-21 (2003).

13) Sinha-Datta U., Horikawa I., Michishita E., Datta A., Sigler-Nicot J. C., Brown M., Kazanji M., Barrett J. C., Nicot C., Blood, 104, 25232531 (2004).

14) Greider C. W., Blackburn E. H., Cell, 43, 405-413 (1985).

15) Greider C. W., Blackburn E. H., Nature (London), 337, 331-337 (1989).

16) Devemy E., Li B., Tao M., Horvath E., Chopra H., Fisher L., Nayini J., Creech S., Venugopal P., Yang J., Kaspar C., Hsu W., Preisler H. D., Leuk. Res., 25, 783-791 (2001).

17) Pommier Y., Sordet O., Antony S., Hayward R. L., Kohn K. W., Oncogene, 23, 2934-2949 (2004)

18) Jäättelä M., Oncogene, 23, 2746-2756 (2004).

19) Min Y. H., Lee S., Lee J. W., Chong S. Y., Hahn J. S., Ko Y. W., Br. J. Haematol., 93, 928-930 (1996).

20) Kanno S., Higurashi A., Watanabe Y., Shouji A., Asou K., Ishikawa
M., Toxicol. Lett., 152, 149-158 (2004).

21) Kanno S., Hiura T., Ohtake T., Koiwai K., Suzuki H., Ujibe M., Ishikawa M., Clin. Chim. Acta, 377, 144-149 (2007).

22) Kanno S., Matsukawa E., Miura A., Shouji A., Asou K., Ishikawa M., Biol. Pharm. Bull., 26, 964-968 (2003).

23) Capizzi R. L., Yang J. L., Cheng E., Bjornsson T., Sahasrabudhe D., Tan R. S., Cheng Y. C., J. Clin. Oncol., 1, 763-771 (1983).

24) Dumont A., Hehner S. P., Hofmann T. G., Ueffing M., Droge W., Schmitz M. L., Oncogene, 18, 747 -757 (1999).

25) Geller H. M., Cheng K. Y., Goldsmith N. K., Romero A. A., Zhang A. L., Morris E. J., Grandison L., J. Neurochem., 78, 265-275 (2001).

26) Franco A. V., Zhang X. D., Van Berkel E., Sanders J. E., Zhang X. Y., Thomas W. D., Nguyen T., Hersey P., J. Immunol., 166, 5337-5345 (2001).

27) Olivier S., Robe P., Bours V., Biochem. Pharmacol., 72, 1054-1068 (2006).

28) Boklan J., Nanjangud G., MacKenzie K. L., May C., Sadelain M., Moore M. A., Cancer Res., 62, 2104-2114 (2002).

29) Haendeler J., Hoffmann J., Rahman S., Zeiher A. M., Dimmeler S., FEBS Lett., 536, 180-186 (2003).

30) Kim J. H., Lee G. E., Kim J. C., Lee J. H., Chung I. K., Mol. Cells, 13, 228-236 (2002).

31) Incles C. M., Schultes C. M., Kelland L. R., Neidle S., Mol. Pharmacol., 64, 1101-1108 (2003).

32) Ward R. J., Autexier C., Mol. Pharmacol., 68, 779—786 (2005).

33) Kuranaga N., Shinomiya N., Mochizuki H., BMC Cancer, 1, 10 (2001).

34) Levine A. J., Cell, 88, 323-331 (1997).

35) Nuessler V., Stotzer O., Gullis E., Pelka-Fleischer R., Pogrebniak A., Gieseler F., Wilmanns W., Leukemia, 13, 1864-1872 (1999).

36) Leonard J. R., D'Sa C., Cahn B. R., Korsmeyer S. J., Roth K. A., Brain Res. Dev. Brain Res., 128, 187-190 (2001).

37) Besirli C. G., Deckwerth T. L., Crowder R. J., Freeman R. S., Johnson E. M., Jr., Cell Death Differ, 10, 1045-1058 (2003).

38) Martin-Aragon S., Mukherjee S. K., Taylor B. J., Ivy S. P., Fu C. H., Ardi V. C., Avramis V. I., Anticancer Res., 20, 139-150 (2000).

39) Muller M., Wilder S., Bannasch D., Israeli D., Lehlbach K., Li-Weber M., Friedman S. L., Galle P. R., Stremmel W., Oren M., Krammer P. H., J. Exp. Med., 188, 2033-2045 (1998).

40) Landowski T. H., Shain K. H., Oshiro M. M., Buyuksal I., Painter J. S., Dalton W. S., Blood, 94, 265-274 (1999).

41) Hofmann T. G., Will H., Cell Death Differ, 10, 1290-1299 (2003).

42) Debatin K. M., Krammer P. H., Oncogene, 23, 2950-2966 (2004).

43) Chan H., Bartos D. P., Owen-Schaub L. B., Mol. Cell Biol., 19, 2098 2108 (1999). 